\title{
Decreased The Anxiety Scale of Hemodialysis Patients With The Spiritual Emotional Freedom Technique (SEFT) and The Autogenic Relaxation
}

\author{
Liza Fitri Lina ${ }^{1}$, Hazaroh Eldis Sabriyanti ${ }^{1}$, Andry Sartika ${ }^{1}$
}

${ }^{1}$ Universitas Muhammadiyah Bengkulu, Indonesia

\section{Article Info}

\section{Article History: \\ Accepted December 29th, 2019}

\section{Keywords:}

Spiritual Emotional Freedom

Technique (SEFT),

Autogenic Relaxation,

Anxiety

\section{INTRODUCTION}

Kidney failure is one of the frightening diseases due to there is no cure for it. The incidence of this disease has been increasing rapidly and the sufferer can be anyone both male and female (old or young), and young is no guarantee for not affected by this disease. ${ }^{1}$

One of the management efforts for patients with chronic kidney failure is through hemodialysis. Clients who will undergo hemodialysis experience depression, fear, and anxiety. Many impacts of this disease like excessive anxiety and not being handled properly. This becomes the obstacle in
Abstract

Problems that can be rendered by hemodialysis include anxiety, relationships in marriage, and disobedience in diet and medicine, limitations in lifestyle and threat of death. The purpose of this study was to find out the comparison between the Spiritual Emotional Freedom hemodialysis patients. The research design employed Quasy Experiment Without Control Group Design. The results of independent t-test analysis in the Emotional Spiritual intervention group Freedom Technique (SEFT) otained results $p=0,000$, in the Autogenic Relaxation intervention group showed that $\mathrm{p}=0.184$. The study indicates that there was no difference between the Spiritual Emotional Freedom Technique (SEFT) and Autogenic Relaxation on decreasing the anxiety scale of hemodialysis patients. It is such as Spiritual Emotional Freedom Technique (SEFT) and Autogenic Relaxation to degrade the anxiety scale of hemodialysis patients.

Corresponding author:

Liza Fitri Lina

lizafitrilina@umb.ac.id

South East Asia Nursing Research, Vol 1 No 3, December 2019

ISSN:2685-032X

DOI: https://doi.org/10.26714/seanr.1.3.2019.142-147

overall behavior and leads to the emergence of symptoms of mental disorders. ${ }^{2}$ The effort that can be done to overcome the anxiety of patients through hemodialysis; such as Emotional Spiritual Freedom Technique, which combines the Spiritual power and Energy psychology and uses autogenic relaxation is a relaxation that comes from within oneself in the form of words or a few short sentences can also be thoughts that can make our minds at ease. ${ }^{3}$

There are many studies that have done in term of SEFT, which are useful for overcoming emotional problems, another research has proved that SEFT therapy can reduce high blood pressure. ${ }^{4}$ There is an 
influence of autogenic relaxation therapy on depression among the elderly. ${ }^{3}$ While other respondents told that they involved more in activities in the nursing home. Other researchers who found that there was a significant influence between autogenic relaxation therapy on anxiety levels in third-trimester primigravida mothers. ${ }^{5}$

\section{METHODS}

This research used numbers; it gets to start from data collection, interpretation, and description of the results. Besides that, to allow a better understanding of research will be presented through tables, graphs, charts, pictures or other views. This study was an experimental Quasy to investigate the comparison between the effectiveness of the Emotional Spiritual Freedom Technique (SEFT) and Autogenic Relaxation on the anxiety scale of hemodialysis patients. The type of this research used a quantitative method by using a quasiexperimental design; pre-post equivalent test without control group design, in which this study contained initial measurements (Pre-test) and final measurements (Posttest). The conclusion is obtained by comparing the pre-test and post-test data between treatment groups. The measurements were carried out 2 times toward 2 groups, namely group 1 with Spiritual Emotion Freedom Technique (SEFT), and group 2 with Autogenic Relaxation.

\section{RESULTS}

\section{Anxiety Scale in Hemodialysis Patients Before and after Spiritual Emotional Freedom Technique Intervention.}

Based on Table 1 can be seen that the anxiety scale in hemodialysis patients prior to the Spiritual Emotional Freedom Technique (SEFT) intervention is 7 respondents (46.7\%) experiencing moderate anxiety.
Table 1 can be seen that the anxiety scale in hemodialysis patients after the Spiritual Emotional Freedom Technique (SEFT) intervention, namely 11 respondents (73.3\%) experienced mild anxiety. table 1 shows that $p$-value $=0,000$ is obtained, it can be concluded that there is an influence between the Spiritual Emotional Freedom Technique (SEFT) on the anxiety scale of hemodialysis patients.

Table 1. Anxiety Scale in Hemodialysis Patients Before and after SEFT Intervention

\begin{tabular}{lccccc}
\hline \multirow{2}{*}{\multicolumn{1}{c}{ Indicators }} & \multicolumn{2}{c}{ pre } & \multicolumn{2}{c}{ post } & \multirow{2}{*}{ p } \\
\cline { 2 - 5 } & $\mathbf{f}$ & $\mathbf{\%}$ & $\mathbf{f}$ & $\mathbf{\%}$ & \\
\hline There is no anxiety & 0 & 0,0 & 2 & 13,3 & \\
Mild anxiety & 3 & 20,0 & 11 & 73,3 & \\
Medium anxiety & 7 & 46,7 & 2 & 13,3 & 0,000 \\
Severe anxiety & 5 & 33,3 & 0 & 0,0 & \\
Panic & 0 & 0,0 & 0 & 0,0 & \\
\hline
\end{tabular}

\section{Anxiety Scale in Hemodialysis Patients Before and after Autogenic Relaxation Intervention.}

Base on Table 2 can be seen that the anxiety scale in hemodialysis patients prior to the intervention of Autogenic Relaxation is 11 respondents (73.3\%) experiencing moderate anxiety. Based on Table 2 can be seen that the anxiety scale in hemodialysis patients before the intervention of Autogenic Relaxation is 8 respondents $(80.0 \%)$ do not experience anxiety. Based on Table 2 obtained p-value $=0,000$, it can be concluded that there is an influence between autogenic relaxation on the anxiety scale of hemodialysis patients.

Table 2. Anxiety Scale in Hemodialysis Patients before and after Autogenic Relaxation Intervention

\begin{tabular}{lccccc}
\hline \multirow{2}{*}{\multicolumn{1}{c}{ Indicators }} & \multicolumn{2}{c}{ pre } & \multicolumn{2}{c}{ post } & \multirow{2}{*}{ p } \\
\cline { 2 - 5 } & $\mathbf{f}$ & $\mathbf{\%}$ & $\mathbf{f}$ & $\mathbf{\%}$ & \\
\hline There is no anxiety & 0 & 0,0 & 8 & 53,3 & \\
Mild anxiety & 1 & 6,7 & 3 & 20,0 & \\
Medium anxiety & 11 & 73,3 & 4 & 26,7 & 0,000 \\
Severe anxiety & 3 & 20,0 & 0 & 0,0 & \\
Panic & 0 & 0 & 0 & 0,0 & \\
\hline
\end{tabular}




\section{Comparison between Spiritual Emotional Freedom Technique (SEFT) and Autogenic Relaxation on the Reduction of the Anxiety Scale of Hemodialysis Patients}

Based on Table 3, p-value $=0.184$ is obtained, it can be concluded that there is no difference between the Spiritual Emotional Freedom Technique (SEFT) and autogenic relaxation on the decrease in anxiety scale of hemodialysis patients.

Table 3. Comparison between the Spiritual Emotional Freedom Technique (SEFT) and Autogenic Relaxation for Reducing Anxiety Scale in Hemodialysis Patients

\begin{tabular}{lccc}
\hline \multicolumn{1}{c}{ Indicators } & SEFT & $\begin{array}{c}\text { Autogenic } \\
\text { Relaxations }\end{array}$ & $\mathrm{p}$ \\
\hline $\begin{array}{l}\text { Anxiety Scale, } \\
\text { mean (SD) }\end{array}$ & $\begin{array}{c}17,07 \\
(4,250)\end{array}$ & $\begin{array}{c}14,53 \\
(5,805)\end{array}$ & 0,184 \\
\hline
\end{tabular}

\section{DISCUSSION}

The results of this study showed that the majority of anxiety scales in hemodialysis patients before giving intervention of the Spiritual Emotional Freedom Technique (SEFT) were $46.7 \%$ of 7 respondents or moderate anxiety. Based on the research results from the majority of respondents before giving Emotional Spiritual Freedom Technique (SEFT) intervention to reduce anxiety in chemotherapy patients at SMC Telogorejo Hospital on a moderate anxiety scale. ${ }^{6}$ Anxiety is an emotional condition with the emergence of discomfort in a person, and is a vague experience accompanied by feelings of helplessness and uncertainty caused by something that is not yet clear. ${ }^{7}$

The results of this study indicated that the majority of disorders scale in hemodialysis patients after conducting intervention Spiritual Emotional Freedom Technique (SEFT) were $73.3 \%$ of 11 respondents, which was in mild anxiety. The related study that has done there found significant differences between levels of depression, anxiety, and stress before and after SEFT intervention ( $\mathrm{p}<0.05)$, between the intervention group and the control group $(\mathrm{p}$ $<0.05) .{ }^{8}$ SEFT intervention helps to reduce depression, anxiety, and stress among chronic kidney failure patients. Spiritual is able to build self-confidence, bring calm, relax, and feel the presence of God Almighty, as a result, it can stimulate the hypothalamus for reducing the production of CRF (Corticotrophin Releasing Factor). Moreover, it further stimulates the anterior pituitary gland to reduce the production of ACTH (Adreno Cortico Tropin Hormone). This hormone stimulates the adrenal cortex to reduce the secretion of stress hormones like cortisol, so that heart rate, high blood pressure, and muscle tension. ${ }^{9}$

The results of this study indicated that the majority of anxiety scale in hemodialysis patients before giving the Autogenic Relaxation intervention was moderate anxiety from 11 respondents $(73.3 \%)$. Based on research results the majority of respondents before giving the autogenic relaxation intervention to reduce anxiety in pre-operation patients at Ungaran District Hospital were on a moderate scale. The way to overcome anxiety through relax effort. ${ }^{10}$ Relaxation is an essential way that is treated to reduce muscle tension, which can improve pulse, blood pressure and breathing. An autogenic relaxation is a simple form that can have extraordinary effect. $^{11}$

The results of this study indicated that the majority of anxiety scale in hemodialysis patients after conducting Autogenic Relaxation intervention was 8 respondents (53.3\%) without anxiety. Based on research results the majority of respondents after giving an autogenic relaxation intervention to reduce anxiety in pregnant women at BPM Lismarini and BPM Kustirah Palembang was on a scale of no anxiety ${ }^{12}$

The purpose of the practice of autogenic relaxation is to emphasize self-suggestion to be more calm, light and warm so that the body relaxes. The changing occurs during 
and after carrying out autogenic relaxation effects on the work of the autonomic nerve. Emotional gives the response and the calming effects caused by this relaxation change the sympathetic dominant physiology into the dominant parasympathetic system. ${ }^{13}$

Based on the results of statistical tests (Dependent T-Test), it is known that the value of $p$ value $=0,000$, then there was an influence between the Spiritual Emotional Freedom Technique (SEFT) on the anxiety scale of hemodialysis patients. \%). Based on research results the statistical test results with the Wilcoxon signed-rank test obtained value $=0,000$, with a value $<(0.05)$, then $\mathrm{H}_{0}$ is rejected. This showed there was an effect of SEFT on the anxiety of climacteric women at RW 6, Pedalangan Subdistrict, Banyumanik District, Semarang, Central Java. Suggestion for climacteric women, SEFT therapy can be recommended as an alternative therapy to overcome the anxiety of climacteric women. ${ }^{9}$

Anxiety is an unclear and pervasive concern, which is related to the feelings of uncertainty and harmless. SEFT therapy is useful to help someone becomes more relaxed and able to deal with severe situations or circumstances in his/her life because there is the flow of positive energy systems and this form of positive affirmation that makes SEFT therapy can be effective. ${ }^{14}$ Spiritual-based interventions are very suitable for helping in achieving these meditative conditions. Coupled with tapping can stimulate the release of antistress hormones so that subjects can decrease anxiety. ${ }^{15}$ Furthermore, the SEFT technique is divided into the full and core versions, which stimulate key points along the 12 energy pathways (meridian energy) of the body. Stimulating body meridian points with the same knock intensity for 1015 minutes can help reduce anxiety and make feelings feel calmer, more comfortable and stimulate the release of endorphins that function as happiness hormones. ${ }^{14}$

Based on the results of statistical tests, it is known that the $\mathrm{p}$-value $=0,000$, then $\mathrm{H}_{\mathrm{o}}$ is rejected and $\mathrm{H}_{\mathrm{a}}$ is received because there was an influence between autogenic relaxation on the anxiety scale of hemodialysis patients. Based on research results "The Effect of Nursing Interventions on Autogenic Relaxation Techniques on Reducing Anxiety Levels in Preoperative Patients". She found there was an influence on the level of anxiety before and after autogenic relaxation techniques on preoperation patients with $\mathrm{p}$-value $0.001 .{ }^{10}$

Autogenic exercise is used for stress and anxiety management because it is simple and its result is very deep, easy to do, can be done at any time, not related to culture or religion. Importantly, this exercise can control the work of the autonomic nervous system (sympathetic and parasympathetic nervous system balance). ${ }^{5}$

The body feels warm, is a result of peripheral arteries undergoing vasodilation, while decreased body muscle tension results in a mild sensation. Changes that occur during and after relaxation affect the work of the autonomic nerve. Emotional responses and the calming effects caused by this relaxation change the physiological dominant sympathetic into the dominant parasympathetic system. ${ }^{16}$

Based on the results of the independent $\mathrm{T}$ test, $\mathrm{pValue}=0.184$, it can be concluded that $\mathrm{H}_{\mathrm{a}}$ is rejected and $\mathrm{H}_{0}$ is accepted because there was no difference between the Spiritual Emotional Freedom Technique (SEFT) with autogenic relaxation toward the decreasing of anxiety scale of hemodialysis patients. Complementary therapy is holistic and non-biomedical therapy that has been recognized and can be used as a companion to medical or pharmacological therapy. Basically, complementary therapy in the nursing system aims to achieve harmony and 
balance in a person. One of the complementary therapies recommended by researchers is Spiritual Emotional Freedom Technique (SEFT) and Autogenic Relaxation. The advantages of these they do not cause side effects, like cheaper, easier, safer, faster and simpler. ${ }^{3}$ It is because SEFT only uses spiritual and tapping elements, in which medically tapping is also not dangerous. So that SEFT therapy can be done by anyone. In addition, SEFT therapy is also universal, meaning it can be used based on the background of the client's beliefs. ${ }^{17}$

Autogenic relaxation is a relaxation technique based on concentration by using body perception that has health benefits to allow the body to feel changes in the body's physiological responses, including emotional, sensory and subjective. ${ }^{18}$

In autogenic relaxation, the thing that becomes the main recommendation is surrender to oneself, it allows various areas in the body (arms, hands, legs, and feet) to be warm and heavy. This warm and severe sensation is caused by a shift in blood flow (from the center of the body to the desired area of the body), which acts like an internal message, soothing and relaxing the muscles around it. ${ }^{19}$

\section{CONCLUSION}

The Spiritual Emotional Freedom Technique (SEFT) and autogenic relaxation can reduce the anxiety scale of hemodialysis patients. the two therapies had no difference in reducing the patient's anxiety scale.

\section{ACKNOWLEDGMENTS}

Thank you to all of the respondents, RSUD DR. M. YUNUS Bengkulu and those who have helped this research.

\section{CONFLICTS OF INTEREST}

Neither of the authors has any conflicts of interest that would bias the findings presented here.

\section{REFERENCES}

1. Manurung M. Faktor-Faktor Yang Mempengaruhi Tingkat Kecemasan Pasien Hemodialisa Di RSU HKBP Balige Kabupaten Toba Samosir Tahun 2018. J Keperawatan Prior. 2018;1(2):38-50.

2. Rahman A, Heldawati, Sudirman. Hubungan tindakan hemodialisais dengan tingkat kecemasan pasien di ruangan hemodialisa RSUD. Labuang Baji pemprov sulawesi selatan. 2014;4:619-622.

3. Vidya PP, Dedi S, Evangeline H. Pengaruh Terapi Relaksasi Autogenik Terhadap Depresi Pada Lansia Di BPS Tresna Werdha Ciparay. J Keperawatan BSI. 2018;VI(Vol 6, No 2 (2018): Jurnal Keperawatan):150-155.

4. Faridah VN. Pengaruh Keperawataan Spiritual Emotional Freedom Technique (SEFT) Islami Terhadap Tekanan Darah Penderita Hipertensi Usia 45-59 Tahun di RSUD DR. Soegiri Lamongan. SURYA. 2012;02(VII):1-14.

5. Farada RA. Pengaruh Teknik Relaksasi Autogenik terhadap Tingkat Kecemasan Pada Ibu Primigravida Trimester III di Wilayah Kerja Puskesmas Kotakulon Kabupaten Bondowoso. Progr Stud Ilmu Keperawatan Univ Jember. 2011.

6. Kartikodaru, Hartoyo WM. Pengaruh Pemberian Spiritual Emotional Freedom Technique (SEFT) Terhadap Penurunan Kecemasan Pasien Kemoterapi Di SMC RS Telogorejo. J Ilmu Keperawatan dan Kebidanan. 2015;111(479):18. doi:10.1192/bjp.111.479.1009-a

7. Annisa DF, Ifdil I. Konsep Kecemasan (Anxiety) pada Lanjut Usia (Lansia). Konselor. 2016;5(2):93. doi:10.24036/02016526480-000

8. Bakara MD, Ibrahim K, Sriati A. Efek Spiritual Emotional Freedom Technique terhadap Cemas dan Depresi, Sindrom Koroner Akut. 2013;1(April 2013):48-55.

9. Aulianita, Y. \& Sudarmiati S. Pengaruh spiritual emotional freedom technique terhadap kecemasan wanita klimakterium di rw 6 kelurahan pedalangan kecamatan banyumanik kota semarang jawa tengah. Pros Semin Nas 
Keperawatan

2015;(November):178-185.

10. Tiana Y. Pengaruh intervensi keperawatan teknik relaksasi autogenik terhadap penurunan tingkat kecemasan pada pasien pre operasi di rsud ungaran. 2005:1-11.

11. Priyo, Margono NH. Efektifitas Relaksasi Autogenik \& Akupresure Menurunkan Sakit Kepala \& Tekanan Darah pada Lansia Hipertensi. PROFESI (Profesional Islam. 2018;15(2):34-44.

12. Sulastri. Pengaruh Teknik Relaksasi Autogenik Terhadap Tingkat Kecemasan Ibu Hamil Di BPM Lismarini Dan BPM Kustirah Palembang Tahu.; 2018.

13. Fitriani Y, Alsa A. Relaksasi Autogenik untuk Meningkatkan Regulasi Emosi pada Siswa SMP. 2015;1(3):149-162.

14. Rofacky HF dan FA. Pengaruh Terapi Spiritual Emotional Freedom Technique (SEFT) Terhadap Tekanan Darah Penderita Hipertensi. J Keperawatan Soedirman (The Soedirman J Nursing). 2015;2(1):17-23. doi:http://dx.doi.org/10.20884/1.jks.2013.8.2. 470

15. Yuniarsih SM. Penggunaan SEFT ( Spiritual
Emotional Freedom Technique ) untuk membantu Ibu hamil menurunkan kecemasan menghadapi Persalinan. STIKES PKU Muhammadiyah Surakarta. 2018;(i):262-270.

16. Dewi WNP, Widari NP. Teknik Relaksasi Autogenik Dan Relaksasi Otot Progresif Terhadap Tekanan Darah Pada Lansia Dengan Hipertensi. Semin Nas dan Work Publ Ilm. 2014;4(2):68-79.

17. Nurwa MS. Analysis of Implementation of Spritual Emotion Freedom Technique ( SEFT ) Therapy in Psychological Disorders ( Stress , Anxious and Depression ) : a Literature Review Analysis of Implementation of Spritual Emotion Freedom Technique ( Seft ) Therapy in Psy. 2018;(August).

18. Aji SB, Armiyati Y, Sn SA. Efektifitas antara Relaksasi Autogenik dan Slow Deep Breathing Relaxation Terhadap Penurunan Nyeri Pada Pasien Post Orif di RSUD Ambarawa. J Ilmu Keperawatan dan Kebidanan. 2015;002:1-12.

19. Supriadi D, Hutabarat E, Putri VP. Pengaruh Terapi Relaksasi Autogenik Terhadap Depresi pada Lanjut Usia di Balai Perlindungan Sosial Tresna Werdha Ciparay Bandung. J Kesehat Kartika. 2015;10(2):56-67. 